\title{
Sarapan dan Faktor yang Berhubungan dengan Hasil Tes Kecepatan dan Ketelitian pada Remaja
}

Tristina Wardani, ${ }^{*}$ IGAN Sugitha Adnyana, ${ }^{*}$ IGA Trisna Windiani, ${ }^{*}$ Soetjiningsih, ${ }^{*}$ Luh Kadek Pande Ary Susilawati**

*Bagian Ilmu Kesehatan Anak, ${ }^{* *}$ Program Studi Psikologi Fakultas Kedokteran Universitas Udayana/RSUP Sanglah Denpasar

Latar belakang. Konsumsi sarapan berdampak positif pada remaja, yaitu meningkatkan kecukupan makanan, penurunan risiko kelebihan berat badan, obesitas dan, meningkatkan fungsi kognitif. Remaja yang melewatkan sarapan memiliki masalah perhatian lebih banyak yang memengaruhi performa belajar. Tes kecepatan dan ketelitian (differential aptitude test) digunakan untuk mengukur respon terhadap tugas atau pekerjaan, yang meliputi kecepatan persepsi, respon terhadap kombinasi huruf-angka, ingatan jangka pendek, pemahaman simbol, bekerja secara detail, dan kesuksesan akademik.

Tujuan. Mengetahui hubungan sarapan dengan hasil tes kecepatan dan ketelitian pada remaja.

Metode. Penelitian ini menggunakan rancangan penelitian observasional analitik dengan desain potong lintang. Pemilihan sekolah menengah pertama (SMP) di Kotamadya Denpasar menggunakan metode purposive.

Hasil. Pelajar SMP yang mengikuti penelitian 175 orang. Pada analisis multivariat regresi logistik didapatkan sarapan, jenis kelamin perempuan dan durasi tidur $\geq 9$ jam memiliki hubungan dengan hasil tes kecepatan dan ketelitian yang baik secara signifikan ( $\mathrm{p}=0,005$; OR 2,5; IK95\%: 1,322-4,924), (p=0,001; OR 2,9; IK95\%: 1,545-5,764) dan (p =0,04; OR 1,9; IK95\%: 1,028-3,874). Kesimpulan. Sarapan, jenis kelamin perempuan, dan durasi jam tidur $\geq 9$ jam secara signifikan memiliki hubungan dengan hasil tes kecepatan dan ketelitian yang baik. Sari Pediatri 2018;20(1):31-6

Kata kunci: sarapan, tes kecepatan dan ketelitian, remaja, differential aptitude test

\section{Breakfast and Factors Associated with the Results of Speed and Accuracy Test in Adolescents}

Tristina Wardani, ${ }^{*}$ IGAN Sugitha Adnyana, ${ }^{*}$ IGA Trisna Windiani, ${ }^{*}$ Soetjiningsih, ${ }^{*}$ Luh Kadek Pande Ary Susilawati**

Background. Breakfast consumption has been known to have positive effect in adolescents which increase the nutrition, decrease the risk of overweight, obesity, and improve cognitive function. Adolescents who skipped breakfast have attention problems which affect their academic performance. Speed and accuracy test (Differential Aptitude Test) measure the response that involves perceptual speed, numbers-and-letters combination, short-term memory, symbol understanding, working in detail and academic success.

Objective. To know the relationship of breakfast and the results of speed and accuracy test in adolescents.

Methods. This is a cross-sectional analytic observational research. Purposive sampling was used to select one public Junior High School (JHS) and one private Junior High School in Denpasar.

Results. A hundred and seventy-five JHS students has participated in this study. Multivariate logistic regression analysis showed that breakfast, female sex, and sleep duration $\geq 9$ hours had a significant association with the good results of speed and accuracy test $(p=0.005$; OR 2.5; 95\% CI 1.332-4.924), ( $p=0.001$; OR 2.9; 95\% CI 1.545-5.674) and ( $\mathrm{p}=0.04$; OR 1.9; $95 \%$ CI 1.028-3.874).

Conclusion. Breakfast, female sex, and sleep duration $\geq 9$ hours had a significant association with the good results of speed and accuracy test. Sari Pediatri 2018;20(1):31-6

Keywords: breakfast, speed and accuracy test, adolescent, differential aptitude test

Alamat korespondensi: Tristina Wardani. Departemen Ilmu Kesehatan Anak Fakultas Kedokteran Universitas Udayana, Email: tristinawardani@ gmail.com 
Tristina Wardani dkk: Sarapan dan faktor yang berhubungan dengan hasil tes kecepatan dan ketelitian pada remaja

$\mathrm{R}$ emaja merupakan generasi muda yang berperan besar menentukan masa depan bangsa. Sebanyak $29 \%$ penduduk dunia terdiri atas remaja, $80 \%$ di antaranya tinggal di negara berkembang. ${ }^{1}$ Berdasarkan Riset Kesehatan Dasar (Riskesdas) 2013, remaja usia 10-19 tahun sebesar 26,2\%. ${ }^{2}$ Gambaran yang khas pada remaja, yaitu pencarian identitas, upaya untuk ketidaktergantungan dan diterima di lingkungannya, kepedulian akan penampilan, rentan terhadap masalah komersial, dan tekanan dari teman sekelompok serta kurang peduli akan masalah kesehatan. Hal tersebut akan mendorong remaja kepada pola makan yang tidak menentu. ${ }^{3}$

Prevalensi tidak sarapan pada anak dan remaja dilaporkan semakin meningkat. ${ }^{4}$ Berdasarkan Riskesdas 2010, 16,9\%-50\% anak usia sekolah dan remaja di Indonesia tidak sarapan. Remaja yang tidak sarapan dilaporkan memiliki lebih banyak masalah perhatian yang memengaruhi performa belajar. ${ }^{3}$ Beberapa studi menyimpulkan adanya hubungan antara sarapan dengan fungsi kognitif dan performa belajar, sementara terdapat studi lain yang menyatakan tidak.

Sarapan digambarkan sebagai makan yang paling penting dalam sehari karena menyumbang kebutuhan asupan gizi dan energi harian yang penting. ${ }^{5}$ Konsumsi sarapan memiliki sejumlah dampak positif pada remaja, yaitu meningkatkan kecukupan makanan, penurunan risiko kelebihan berat badan atau obesitas dan meningkatkan fungsi kognitif. ${ }^{4}$ Beberapa studi telah meneliti hubungan sarapan dengan fungsi kognitif, baik pada anak maupun remaja, menggunakan berbagai instrumen, antara lain, mini mental state examination, continous performance task, Kaufman assessment battery for children-II tests, Wechsler intelligence scale for children-III dan differential aptitude test (DAT).

Differential aptitude test merupakan tes kemampuan yang terdiri atas 7 macam tes, yaitu tes berhitung, penalaran, pola, pengertian mekanik, kecepatan dan ketelitian, penalaran verbal dan pemakaian bahasa, yang masing-masing tes dapat berdiri sendiri. Tes kecepatan dan ketelitian mengukur respon terhadap tugas atau pekerjaan yang menyangkut kecepatan persepsi, respon terhadap kombinasi huruf-angka, dan ingatan jangka pendek. ${ }^{7}$ Tes kecepatan dan ketelitian juga berhubungan dengan pemahaman simbol, bekerja secara detail, dan kesuksesan akademik. ${ }^{8}$

Tes kecepatan dan ketelitian memiliki nilai validitas baik berdasarkan determination index, Kaiser-MeyeOlkin measure of sampling adequacy dan Bartlett's test of sphericity, yaitu 8,55E-045; 0,96; dan tingkat signifikan 0,000. Realibilitas tes ini baik, masing-masing 0,978; 0,723; 0,721 dengan uji realibilitas Gutmann's Lambda-3 dan Cronbach's Alpha, Spearman-Brown split half, Guttmann split half. ${ }^{8}$ Saat ini belum ada penelitian yang mencari hubungan sarapan dengan fungsi kognitif pada remaja menggunakan tes kecepatan dan ketelitian. Tujuan utama penelitian ini adalah membuktikan hubungan sarapan dan faktor yamg memengaruhi hasil tes kecepatan dan ketelitian pada remaja.

\section{Metode}

Penelitian ini menggunakan rancangan penelitian observasional analitik dengan desain potong lintang. Pemilihan sekolah menengah pertama di wilayah Kotamadya Denpasar secara purposive sampling, yaitu 1 sekolah negeri dan 1 sekolah swasta. Kriteria inklusi penelitian ini adalah siswa SMP kelas 7-8 yang bersekolah di SMPN 6 Denpasar dan SMP Harapan Denpasar pada bulan Februari 2017. Kriteria eksklusi adalah apabila siswa tidak menyetujui ikut serta dalam penelitian, siswa yang saat pemeriksaan tidak hadir di sekolah, serta apabila siswa tidak sakit saat dilakukan pemeriksaan.

Penelitian ini menggunakan kesalahan tipe $15 \%$, kesalahan tipe II 20\% dengan hipotesis 2 arah. Nilai P1-P2 yang dianggap bermakna adalah 20\% sehingga diperoleh besar sampel minimal adalah 169 orang.

Sarapan yaitu makan dari pukul 06.00 pagi hingga pukul 10.00 pagi sebanyak $20-25 \%$ dari total kalori karbohidrat, protein dan lemak sehari, sesuai angka kecukupan gizi tahun 2013. ${ }^{9}$ Status gizi dibagi menjadi buruk, kurang, baik, lebih, dan obesitas berdasarkan kriteria Waterlow. ${ }^{10}$ Golongan pendapatan, yaitu penghasilan orang tua setiap bulan berdasarkan Badan Pusat Statistik 2014. ${ }^{11}$ Pendidikan orangtua, yaitu jenjang pendidikan terakhir orangtua. Durasi tidur, yaitu waktu yang dihabiskan untuk tidur pada saat malam hari sebelum tes dilakukan. ${ }^{12}$ Jumlah anggota keluarga, yaitu jumlah individu yang tinggal bersama dalam satu atap dan bergantung pada sumber pendapatan yang sama. ${ }^{13}$ Analisis hasil tes kecepatan dan ketelitian dilakukan oleh psikolog, yang dibagi menjadi baik bila nilai 66 hingga 100, dan buruk bila nilai kurang dari 66. 


\section{Hasil}

Jumlah subjek yang memenuhi kriteria inklusi dan eksklusi adalah 175 subjek. Jumlah siswa yang sarapan di kedua sekolah, yaitu 49,7\%. Prevalensi siswa sarapan di sekolah negeri dan di sekolah swasta, yaitu 48,9\% dan 50,6\%. Rasio lelaki dan perempuan pada kelompok sarapan yaitu 1:1,17 dan pada kelompok tidak sarapan yaitu 1:1,74. Prevalensi gizi kurang, baik, lebih, dan obesitas berturut-turut $15,4 \%, 54,2 \%, 17,5 \%, 12,5 \%$. Rentang jumlah penghasilan orang tua, yaitu Rp 2.500.000 hingga Rp 10.000.000. Prevalensi pendidikan tinggi ayah 44\%, dan rendah-menengah ayah $56 \%$. Prevalensi pendidikan tinggi ibu 36\%, dan rendah-menengah ibu 64\%. Jenis sarapan yang dikonsumsi siswa bervariasi, yaitu nasi dan lauk $74 \%$, roti $14,9 \%$, mie $2,2 \%$, susu, $2,2 \%$, sereal $4,5 \%$, dan buah $1,1 \%$.

Tabel 2 menunjukkan analisis bivariat tes kecepatan dan ketelitian. Kami mendapatkan bahwa siswa sarapan memiliki nilai tes kecepatan dan ketelitian 1,4 kali lebih baik dibandingkan tidak sarapan $(\mathrm{p}=0,028$; IK95\%: 1,03-1,81). Analisis multivariat menggunakan uji regresi logistic dengan metode backward, menunjukkan siswa sarapan memiliki tes kecepatan dan ketelitian 2,5 kali lebih tinggi dibandingkan siswa yang tidak sarapan OR 2,5 ( $\mathrm{p}=0,005$; IK95\%: 1,322-4,924). Perempuan memiliki hasil tes kecepatan dan ketelitian 2,9 kali lebih tinggi dibandingkan lelaki OR 2,9 ( $\mathrm{p}=0,001$; IK95\%: 1,545-5,764). Durasi tidur $\geq 9$ jam memiliki hasil tes kecepatan dan ketelitian 1,9 kali lebih tinggi dibandingkan siswa yang tidur $<9$ jam OR 2,9 ( $\mathrm{p}=0,04$; IK95\%: 1,028-3,874) Tabel 3.

Tabel 1. Karakteristik subjek penelitian

\begin{tabular}{|c|c|c|}
\hline \multirow[t]{2}{*}{ Karakteristik } & \multicolumn{2}{|c|}{ Sarapan } \\
\hline & $\begin{array}{c}\mathrm{Ya} \\
(\mathrm{n}=87)\end{array}$ & $\begin{array}{l}\text { Tidak } \\
(\mathrm{n}=88)\end{array}$ \\
\hline Umur, rerata \pm SD (tahun) & $13 \pm 0,7$ & $13,1 \pm 0,6$ \\
\hline \multicolumn{3}{|l|}{ Jenis kelamin, n (\%) } \\
\hline Lelaki & $40(55,5)$ & $32(44,4)$ \\
\hline Perempuan & $47(45,6)$ & $56(54,4)$ \\
\hline \multicolumn{3}{|l|}{ Status gizi, n (\%) } \\
\hline Kurang & $14(51,9)$ & $13(48,1)$ \\
\hline Baik & $48(50,5)$ & $47(49,5)$ \\
\hline Lebih & $16(40,9)$ & $15(59,1)$ \\
\hline Obesitas & $9(40,9)$ & $13(59,1)$ \\
\hline \multicolumn{3}{|c|}{ Tingkat pendidikan ayah, n (\%) } \\
\hline Rendah-menengah & $47(48)$ & $51(52)$ \\
\hline Tinggi & $40(52)$ & $37(48)$ \\
\hline \multicolumn{3}{|c|}{ Tingkat pendidikan ibu, n (\%) } \\
\hline Rendah-menengah & $49(43,7)$ & $63(56)$ \\
\hline Tinggi & $38(60,3)$ & $25(39,7)$ \\
\hline \multicolumn{3}{|l|}{ Golongan pendapatan, $\mathrm{n}(\%)$} \\
\hline Sedang & $17(42,5)$ & $23(57,5)$ \\
\hline Tinggi & $70(51,9)$ & $65(50,3)$ \\
\hline \multicolumn{3}{|l|}{ Jam tidur, jam, n (\%) } \\
\hline$\geq 9$ & $49(45,4)$ & $59(54,6)$ \\
\hline$<9$ & $38(56,7)$ & $29(43,3)$ \\
\hline \multicolumn{3}{|c|}{ Jumlah anggota keluarga, n (\%) } \\
\hline $\operatorname{Kecil}(\leq 4)$ & $60(51,3)$ & $57(48,7)$ \\
\hline Besar $(>4)$ & $27(46,6)$ & $31(53,4)$ \\
\hline
\end{tabular}


Tabel 2. Hasil analisis bivariat tes kecepatan dan ketelitian

\begin{tabular}{|c|c|c|c|c|c|}
\hline \multirow[t]{2}{*}{ Variabel } & \multicolumn{2}{|c|}{ Tes kecepatan dan ketelitian } & \multirow[t]{2}{*}{$\mathrm{p}$} & \multirow[t]{2}{*}{$\mathrm{RP}$} & \multirow[t]{2}{*}{ IK95\% } \\
\hline & Baik, n (\%) & Buruk, n (\%) & & & \\
\hline \multicolumn{6}{|l|}{ Sarapan } \\
\hline Ya & $54(62,1)$ & $33(37,9)$ & 0,028 & 1,4 & $1,03-1,81$ \\
\hline Tidak & $40(45,5)$ & $48(54,5)$ & & & \\
\hline \multicolumn{6}{|l|}{ Jenis kelamin } \\
\hline Perempuan & $66(64,1)$ & $37(35,9)$ & 0,001 & 1,6 & $1,19-2,27$ \\
\hline Lelaki & $28(38,9)$ & $44(61,1)$ & & & \\
\hline \multicolumn{6}{|l|}{ Pendidikan ayah } \\
\hline Tinggi & $44(57,1)$ & $33(42,9)$ & 0,42 & 1,12 & $0,85-1,47$ \\
\hline Rendah-menengah & $50(51)$ & $48(49)$ & & & \\
\hline \multicolumn{6}{|l|}{ Pendidikan ibu } \\
\hline Tinggi & $36(57,1)$ & $27(42,9)$ & 0,49 & 1,1 & $0,83-1,45$ \\
\hline Rendah-menengah & $58(51,8)$ & $54(48,2)$ & & & \\
\hline \multicolumn{6}{|l|}{ Durasi tidur (jam) } \\
\hline$\geq 9$ & $65(60,2)$ & $43(39,8)$ & 0,029 & 1,39 & $1,06-1,9$ \\
\hline$<9$ & $29(43,3)$ & $38(56,7)$ & & & \\
\hline
\end{tabular}

Tabel 3. Hasil analisis multivariat tes kecepatan dan ketelitian

\begin{tabular}{lccc}
\hline Variabel & OR & $\mathrm{p}$ & IK95\% \\
\hline Sarapan & 2,5 & 0,005 & $1,322-4,924$ \\
Jenis kelamin perempuan & 2,9 & 0,001 & $1,545-5,764$ \\
Durasi tidur $\geq 9$ jam & 1,9 & 0,04 & $1,028-3,874$ \\
\hline
\end{tabular}

\section{Pembahasan}

Sarapan merupakan hal yang sangat penting karena menyediakan asupan nutrisi dan kebutuhan energi yang substansial. Beberapa penelitian dilakukan untuk menilai hubungan antara sarapan dan kemampuan kognitif pada anak dan remaja. Tidak semua penelitian mendapatkan efek positif sarapan dengan kemampuan kognitif.

Penelitian ini mendapatkan karakteristik rerata usia subjek pada kelompok sarapan dan tidak sarapan tidak berbeda, yaitu $13 \pm 0,7$ dan $13,1 \pm 0,6$. Analisis multivariat dilakukan pada faktor yang memengaruhi hasil tes kecepatan dan ketelitian. Penelitian ini menunjukkan kelompok subyek yang sarapan memiliki kemungkinan 2,5 kali mendapatkan hasil tes kecepatan dan ketelitian yang baik. Tes kecepatan dan ketelitian yang digunakan pada penelitian ini bertujuan mengukur respon terhadap tugas atau pekerjaan yang menyangkut kecepatan persepsi, respon terhadap kombinasi huruf-angka, dan ingatan jangka pendek. Hasil serupa didapatkan pada beberapa studi, antara lain, studi di Etiopia Selatan pada tahun 2014 terhadap 208 remaja usia 11-13 tahun, didapatkan bahwa remaja yang mengonsumsi sarapan secara rutin mencapai nilai Simultaneous scale dan Pattern Reasoning lebih tinggi, serta sarapan rutin dan tingkat pendidikan ibu berhubungan juga dengan sequential scale secara bermakna. ${ }^{4}$ Hasil studi tahun 2014 pada 80 siswa SMA/SMK di Surakarta mendapatkan hubungan yang bermakna antara sarapan dengan hasil digit symbol test dan digit span test dari subtes Weschler adult intelegence scale (WAIS). ${ }^{14}$

Hasil serupa juga didapatkan pada penelitian tahun 2011 di Inggris, 60 anak usia 12 hingga 15 tahun yang 
sarapan mampu menyelesaikan tes fungsi kognitif Visual search test, Stroop test dan Sternberg paradigm dengan lebih akurat dan cepat. ${ }^{15}$

Berdasarkan studi di India pada anak umur 1113 tahun didapatkan hubungan antara konsumsi sarapan rutin dan tes recall memory segera (perhatiankonsentrasi). Beberapa studi melaporkan bahwa individu yang rutin sarapan mengalami peningkatan perhatian dan fungsi memori jangka pendek. Sebaliknya, tidak sarapan memiliki efek merugikan pada fungsi kognitif, pemecahan masalah, memori jangka pendek, perhatian, dan memori episodik.

Tidur 9 jam atau lebih, dan jenis kelamin perempuan secara bermakna memberikan hasil tes kecepatan dan ketelitian yang baik. Pada penelitian ini didapatkan jenis kelamin memengaruhi hasil tes kecepatan dan ketelitian, perempuan memiliki kemungkinan 2,9 kali mendapat hasil tes yang baik. Hasil berbeda dilaporkan pada suatu studi pada siswa menengah pertama di India tidak didapatkan perbedaan bermakna hasil tes kecepatan dan ketelitian pada lelaki dan perempuan. ${ }^{16}$ Studi lain di Inggris tahun 1992 melaporkan dari 10 ribu anak usia 13-18 tahun yang dilakukan tes DAT, lelaki mendapatkan nilai tinggi pada verbal reasoning test, abstract reasoning, numerical, mechanical reasoning, dan spatial relation, sementara perempuan mendapat nilai tinggi pada tes kecepatan dan ketelitian, mengeja, dan bahasa. ${ }^{6}$ Pengaruh jenis kelamin pada kemampuan kognitif telah dianalisis luas dalam literatur psikologi dan neuropsikologi. Tiga perbedaan utama kemampuan kognitif antara lelaki dan perempuan yang telah dilaporkan, yaitu perempuan memiliki kemampuan verbal lebih tinggi, sementara lelaki lebih cakap dalam kemampuan spasial dan aritmatika. Perbedaan fungsi kognitif pada lelaki dan perempuan juga berhubungan dengan lingkungan, latar belakang pendidikan dan idiosinkrasi kultural. ${ }^{17}$

Penelitian ini menunjukkan durasi tidur $\geq 9$ jam memiliki kemungkinan 1,9 kali mendapatkan hasil tes kecepatan dan ketelitian yang baik. Hasil tersebut sesuai dengan studi di Australia, yaitu remaja yang tidur dengan durasi $<8$ jam memiliki hasil tes memori yang lebih buruk ${ }^{18}$ Studi pada anak usia 7-11 tahun di Kanada tahun 2010 juga mendapatkan kebiasaan tidur dengan durasi lebih panjang pada anak sehat berhubungan dengan tingkat IQ, kompetensi, dan performa akademik yang lebih baik. ${ }^{19}$ Hasil berbeda didapatkan pada studi di Bandung, yaitu siswa SMP yang tidur dengan durasi $<7$ jam memiliki hasil tes memori jangka pendek yang optimal. ${ }^{20}$

Tidur merupakan kebutuhan dasar yang penting bagi manusia untuk pemulihan tubuh dan pikiran. ${ }^{18}$ Waktu tidur rata-rata yang dibutuhkan remaja adalah 9-9,5 jam tiap malam. ${ }^{13}$ Efek menunda tidur pada remaja (ditandai susah tidur dan terbangun tepat waktu) akan berlangsung sepanjang minggu. Hal tersebut berhubungan dengan rata-rata nilai sekolah yang lebih rendah dan meningkatnya insiden kecemasan dan depresi. Studi lain pada anak usia 10-14 tahun dengan durasi tidur selama 5 jam menunjukkan gangguan performa kognitif pada kreativitas verbal dan tugas Wisconsin Card Sorting dibandingkan anak yang tidur selama 11 jam. $^{21}$ Beberapa keterbatasan dalam penelitian ini adalah tidak menggambarkan prevalensi sarapan pada anak remaja, tidak menggali penyebab remaja melewatkan sarapan, tidak menghitung proporsi makronutrien pada sarapan yang dikonsumsi.

\section{Kesimpulan}

Sarapan, durasi jam tidur $\geq 9$ jam dan perempuan memiliki hubungan yang signifikan terhadap hasil tes kecepatan dan ketelitian. Siswa perlu kecepatan dan ketelitian dalam mengerjakan tugas-tugas dan kegiatan belajar di sekolah. Siswa yang sarapan dan cukup tidur sebelum proses belajar dimulai, memiliki nilai tes kecepatan dan ketelitian yang baik, sehingga diharapkan siswa akan lebih baik dalam memahami suatu pelajaran dan pencapaian akademik yang lebih baik.

\section{Daftar pustaka}

1. Pardede N. Masa remaja. Dalam: Narendra MB, Sularyo TS, Soetjiningsih, Suyitno H, Ranuh IGN, penyunting. Buku ajar tumbuh kembang anak dan remaja. Edisi ke-1. Jakarta: CV. Sagung Seto;2002.h. 156-7.

2. Kementerian Kesehatan RI. Riset Kesehatan Dasar. Badan Penelitian dan Pengembangan Kesehatan Kementerian Kesehatan RI; 2013:1-306.

3. Satgas Remaja IDAI. Nutrisi pada remaja. Dalam Dhamayanti M, Endyarni B, Hartanto F, Lestari H, penyunting. Bunga rampai kesehatan remaja. Edisi ke-1. Jakarta: Badan penerbit Ikatan Dokter Anak Indonesia; 2010. h. 29-37.

4. Mahoney CR, Taylor HA, Kanarek RB, Samuel P. Effect of 
Tristina Wardani dkk: Sarapan dan faktor yang berhubungan dengan hasil tes kecepatan dan ketelitian pada remaja

breakfast composition on cognitive processes in elementary school children. Physiol Behav 2005:635-45.

5. Adole AA, Ware MB. Assessment of breakfast eating habits and its association with cognitive performance of early adolesecents (11-13 years) in Shebedino District, Sidama Zone, Southern Ethiopia. J Food Nutr Sci 2014; 2:130-7.

6. Corengia A, Pita M, Mesurado B, Centeno A. Predicting academic performance and attrition in undergraduate students. Revista de Psicologia 2013;19:101-12.

7. Widiawati D. Tes bakat. Diunduh pada 11 Oktober 2016. Didapat dari: URL:Http://www.mercubiana.ac.id.

8. Sunawan. Diagnosa kesulitan belajar. Semarang: UNNES; 2009.h. 42

9. Rajpura R. Development of different aptitude test (DAT) for secondary school students. 2012. Diunduh pada 14 April 2017. Didapat dari: URL:Http://etheses.saurashtrauniversity. edulid/821.

10. Khalida E, Fadlyana E, Somasetia D.H. Hubungan kebiasaan sarapan dengan prestasi belajar dan fungsi kognitif pada anak sekolah dasar. Sari Pediatri 2015;17:89-94.

11. Unit Kerja Koordinasi Nutrisi dan Penyakit Metabolik Ikatan Dokter Anak Indonesia. Asuhan nutrisi pediatrik. Edisi ke-1. Jakarta: Ikatan Dokter Anak Indonesia 2011.h.4-6.

12. Badan Pusat Statistik. Jumlah pendapatan menurut golongan rumah tangga tahun 2014. Diunduh pada 1 Februari 2017. Didapat dari : URL:Http://www.bps.go.id.

13. Owens JA. Sleep Medicine. Dalam: Kliegman RM, Stanton
BF, Geme III JW, Schor NF, Behrman RE, penyunting. Nelson textbook of pediatric. Edisi ke-20. Philadelphia: Elsevier 2016.h.111-23.

14. Mankar J, Chavan D. Differential aptitude testing of youth. Int J Sci Res Pub 2013; 3:1-6.

15. Lentini B, Margawati A. Hubungan kebiasaan sarapan dan status hidrasi dengan konsentrasi berfikir pada remaja [skripsi]. Semarang: Fakultas Kedokteran Universitas Diponegoro, 2014.

16. Cooper S.B. Bandelow S, Nevill M.E. Breakfast consumption and cognitive function in adolescent school children. Physiology and behaviour 2011;103: 431-9.

17. Quasier-Pohl C, Lehmann W. Girl's spatial abilities: charting the contributions of experiences and attitudes in different academic group. Br J Educ Psychol 2002;72:245-60.

18. Gradisar M, Terrill G, Johnston A, Douglas P. Adolescent sleep and working memory performance. Sleep Biol Rhythms 2008:6:146-54.

19. Gruber R, Laviolette R, Deluca P, Monson E, Cornish $\mathrm{K}$, Carrier J. Short sleep duration is associated with poor performance on IQ measures in healthy school-age children. Sleep Med 2010;11:289-94.

20. Solikhin AN, Suryani YD, Zulmansyah. Hubungan antara durasi tidur dengan memori jangka pendek siswa siswi SMP Darul Hikam kota Bandung tahun ajaran 2015-2016. Prosiding pendidikan dokter 2016; 2:833-8.

21. Miller MA, Wright H, Hough J, Cappuccio FP. Sleep and cognition. Sleep and its disorders affect society 2014:3-27. 